
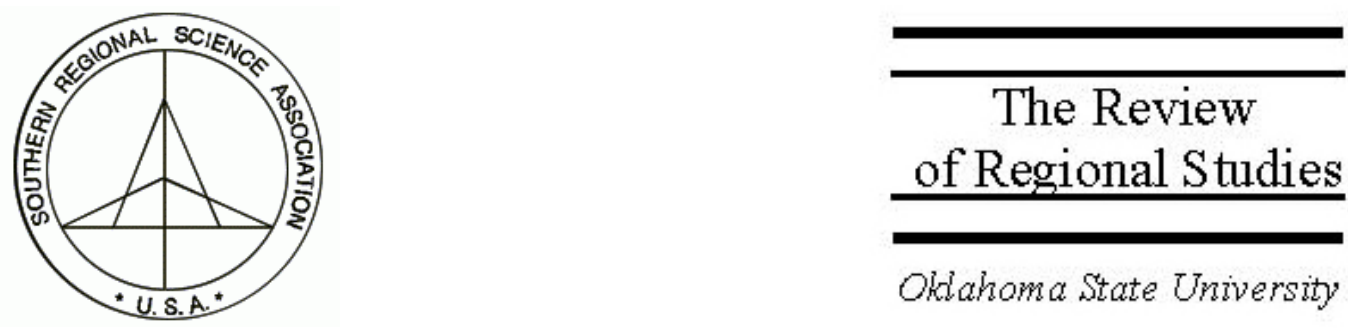

\title{
The Effects of Industry Instability on Sector Entry: The Case of Maine
}

\author{
Todd M. Gabe
}

Department of Resource Economics and Policy, 5782 Winslow Hall, University of Maine, Orono, ME 04469-5782, e-mail: todd.gabe@umit.maine.edu

\begin{abstract}
This paper investigates the effects of industry instability on the entry decisions of a large sample of Maine establishments. Instability is represented by the persistence of industry employment in Maine, measured over 3-month, 6-month, and 12-month intervals. Poisson regression results suggest that the employment persistence measures have a positive effect on the number of establishments that began operations per industry. This suggests that, other things being equal, entrants are attracted to sectors with high regional employment stability.
\end{abstract}

Keywords: Industry entry; Instability; Regional economic growth

JEL classification: L20; R1; R30

I would like to thank two anonymous reviewers and Ron Moomaw for helpful comments and suggestions on an earlier version of the manuscript. Funding for the study was provided by the National Research Initiative of the United States Department of Agriculture, Rural Development Program award number 2003-3540112937. Research was also supported in part by the Maine Agricultural and Forest Experiment Station. MAFES external publication 2793. 


\section{INTRODUCTION}

Previous studies have investigated some of the causes and effects of regional economic instability (Conroy 1975; Brown and Pheasant 1985, 1987; Fawson, Thilmany, and Keith 1998; Smith 1990). Conroy (1975) and Brewer (1985) found that regional industrial diversification reduces instability, while Smith (1990) and Smith and Gibson (1988) found that a high reliance on agricultural, extractive, and tourism-related industries increases regional economic instability. A high level of instability in overall economic activity hurts a region's ability to fund public services over time and may be counterproductive to "traditional rural lifestyles" (Fawson, Thilmany, and Keith 1998).

While much is known about the factors that contribute to overall regional economic instability, a less understood phenomenon is the effect of industry-specific instability on entry decisions. Generally speaking, businesses are attracted to sectors that promise high profits and that have relatively low costs of entry. Fluctuations in industry economic conditions may adversely affect a business's post-entry profits and entry costs. Shortterm, month-to-month fluctuations in industry employment may decrease an entrant's expected future profits because of the costs of recruiting, hiring, training, and firing workers (Dixit 1997). Longer-term instability, if it creates uncertainty about the future, may also discourage industry entry. This is because uncertainty raises the opportunity cost of investments that involve sunk costs, which are likely present at entry (Pindyck 1988). These factors suggest that within any given region, industries with high employment instability will have fewer entrants than sectors with stable employment over time.

This paper investigates the effects of industry-specific regional instability on the entry decisions of a large sample of Maine establishments. Our analysis uses a Poisson regression framework, which has been employed previously to examine industry entry and business location decisions (Chappell, Kimenyi, and Mayer 1990; Guimaraes, Figueiredo, and Woodward 2003). Instability is represented by the 3-month, 6-month, and 12-month persistence of industry employment in Maine. The persistence variables capture the extent to which month-to-month employment gains or losses (i.e., shocks) are maintained over these longer time intervals. Cochrane (1988) took a similar approach to study movements in U.S. GNP; and Fawson, Thilmany, and Keith (1998) used the persistence measure to analyze industry instability in rural Utah counties.

\section{ANALYTICAL FRAMEWORK}

Traditional models of industry entry imply

$$
E=\chi[\pi-F]+u,
$$

where $E$ is the number of establishments that enter an industry in a given time period; $\pi$ represents an establishment's expected post-entry profits; $F$ represents barriers to entry, including an establishment's opportunity cost of entry and profits related to industry 
structure; $\chi$ is the speed with which entrants react to excess profits; and $u$ is an error term (Audretsch 1995; Geroski 1995).

Instability is incorporated into the empirical analysis as a set of persistence variables that measure fluctuations in regional industry employment that take place in short-term (i.e., 3-month and 6-month) and longer-term (i.e., 12-month) cycles. We expect fluctuations in industry economic conditions to discourage entry by increasing the opportunity cost of investment and by decreasing an establishment's expected profits upon entry. Given the sunk costs associated with setting up a new establishment, an entrant's opportunity cost of investment includes the foregone option value of postponing the entry decision to the future (Pindyck 1988). If instability creates uncertainty about the future, this option value - and the opportunity cost of investment - will increase with higher fluctuations in regional industry employment. Even if instability may not lead to uncertainty about the future, the costs of adjusting an establishment's workforce in response to fluctuations in industry economic conditions may lower expected post-entry profits (Dixit 1997).

Previous studies have examined the causes of industry instability, although the emphasis has been primarily on fluctuations in market share (Meisel 1981; McGuckin 1972; Caves and Porter 1978). Caves and Porter (1978) used measures of market disturbances, product differentiation, industry cost structure and technology, and market size and concentration to explain business-level market share instability. They found that exogenous disturbances related to demand instability, import competition, and product innovation increase market share instability. On the other hand, instability is dampened by capital intensity, vertical integration, and the level of market concentration. Meisel (1981) also found that concentration reduces this type of instability, while brand market share instability translates into greater firm market share instability.

Other variables included in the empirical analysis control for traditional entry factors such as industry size and growth, capital requirements, economies of scale, and advertising intensity. Large and rapidly growing industries may experience high entry levels because they can accommodate new establishments with little effect on incumbent sales and market price (Orr 1974). Deutsch (1984); Hause and DuRietz (1984); and Chappell, Kimenyi, and Mayer (1990) found that industry growth rates have a positive effect on entry. Deutsch (1984) and Chappell, Kimenyi, and Mayer (1990) uncovered a positive relationship between entry and industry size.

Industry capital requirements, economies of scale, and advertising may form barriers to entry. Orr (1974) and Chappell, Kimenyi, and Mayer (1990) uncovered a negative relationship between entry and an industry's capital intensity. Hause and DuRietz (1984) found a negative relationship between entry and the average employment size of industry entrants, an indicator of economies of scale. Empirical evidence on the relationship between entry and advertising is mixed. Orr (1974) and Chappell, Kimenyi, and Mayer (1990) found that product promotion discourages entry, presumably because advertising expenditures are a sunk cost (Kessides 1986). On the other hand, advertising may 
facilitate entry because it can decrease the perceived risks of entry (Kessides 1986; Chappell, Kimenyi, and Mayer 1990; Evans and Siegfried 1992). Kessides (1986) uncovered two offsetting effects of advertising on entry, with a positive net effect.

Since the analysis focuses on a single state, it is necessary to control for state-specific factors beyond the industry instability measures that may affect entry. Benefits of industry agglomeration - such as the presence of a skilled work force, availability of specialized inputs, and knowledge spillovers - may increase an entrant's expected profits (Krugman 1991). Likewise, barriers to entry may decrease as a result of a high agglomeration of industry because the workers, financing sources, and other inputs needed to start a business are present in the region (Porter 2000).

\section{DATA}

Table 1 presents descriptive statistics of the variables used in the paper. The analysis focuses on the number of entrants per industry in Maine. The choice set used in the initial analysis consists of 123 three-digit SIC sectors in which ten or more establishments began operations in the state between 1996 and 1999. To be counted as an entrant, the establishment must have employed zero workers in the first quarter of 1996, one or more workers in the first quarter of 1999, and have an "initial liability date" listed in the state's Covered Employment and Wages (ES-202) data files between 1996 and 1999. In previous studies, the most common measure of entry is the net change in the number of establishments operating in an industry (Orr 1974; Deutsch 1984; Kessides 1986; Chappell, Kimenyi, and Mayer 1990). However, Deutsch (1984); Kessides (1986); and Chappell, Kimenyi, and Mayer (1990) suggest that the ideal measure of entry is the gross number of businesses that enter an industry, which is the approach taken in this paper.

The choice set of 123 three-digit SIC industries includes sub-sectors of seven major one-digit SIC industries. The services (34.1 percent) and retail trade (21.1 percent) industries account for over half of the choice set. Just over 10 percent of the choice set is made up of sub-sectors of the manufacturing industry (11.4 percent). The rest of the choice set is comprised of sub-sectors of the finance, insurance, and real estate (8.9 percent); wholesale trade (8.9 percent); construction (8.2 percent); and transportation and public utilities ( 7.4 percent) industries. The three-digit SIC industries included in the choice set had combined employment of 332,987 in the first quarter of 1996 , which is about 70 percent of total state employment at that time.

Instability is represented by the 3-month, 6-month, and 12-month persistence of industry employment. The persistence measures are computed for each $k$-month interval as

$$
\left(\sigma_{k}^{2} / k\right) /\left(\sigma_{i}^{2}\right)
$$


Gabe: The Effects of Industry Instability on Sector Entry: The Case of Maine

TABLE 1

Descriptive Statistics and Variable Definitions

\begin{tabular}{|c|c|c|c|}
\hline Variable & Definition & Mean & $\begin{array}{l}\text { Standard } \\
\text { Deviation }\end{array}$ \\
\hline Entry, 1996 to 1999 & $\begin{array}{l}\text { Number of establishments that entered 3-digit } \\
\text { SIC industry in Maine, } 1996 \text { to } 1999^{\text {a }}\end{array}$ & 55.980 & 71.680 \\
\hline Entry, 1999 to 2000 & $\begin{array}{l}\text { Number of establishments that entered 3-digit } \\
\text { SIC industry in Maine, } 1999 \text { to } 2000^{\text {a }}\end{array}$ & 14.350 & 21.160 \\
\hline $\begin{array}{l}\text { 3-month employment } \\
\text { persistence }\end{array}$ & $\begin{array}{l}\text { 3-month persistence of industry employment in } \\
\text { Maine, January } 1994 \text { to December } 1998^{\text {a }}\end{array}$ & 4.312 & 7.577 \\
\hline $\begin{array}{l}\text { 6-month employment } \\
\text { persistence }\end{array}$ & $\begin{array}{l}\text { 6-month persistence of industry employment in } \\
\text { Maine, January } 1994 \text { to December } 1998^{\text {a }}\end{array}$ & 2.221 & 3.717 \\
\hline $\begin{array}{l}\text { 12-month employment } \\
\text { persistence }\end{array}$ & $\begin{array}{l}\text { 12-month persistence of industry employment in } \\
\text { Maine, January } 1994 \text { to December } 1998^{\text {a }}\end{array}$ & 1.035 & 1.861 \\
\hline $\begin{array}{l}\text { Industry growth, } 1994 \\
\text { to } 1997\end{array}$ & $\begin{array}{l}\text { Percentage change in U.S. employment in 3- } \\
\quad \text { digit SIC sector, } 1994 \text { to } 1997^{\mathrm{b}}\end{array}$ & 0.104 & 0.142 \\
\hline $\begin{array}{l}\text { Industry growth, } 1998 \\
\quad \text { to } 2000\end{array}$ & $\begin{array}{l}\text { Percentage change in U.S. employment in 3- } \\
\quad \text { digit SIC sector, } 1998 \text { to } 2000^{\mathrm{b}, \mathrm{e}}\end{array}$ & 0.075 & 0.075 \\
\hline Industry size, 1995 & U.S. employment in 3-digit SIC sector, $1995^{\text {b }}$ & 530,586 & 779,597 \\
\hline Industry size, 1998 & U.S. employment in 3-digit SIC sector, $1998^{\text {b, e }}$ & 737,123 & 911,382 \\
\hline Investment & $\begin{array}{l}\text { Dollar amount of new structures and investment } \\
\text { per U.S. industry establishment, } 1992^{c}\end{array}$ & 151,840 & 324,377 \\
\hline $\begin{array}{l}\text { Establishment size, } \\
\quad 1995\end{array}$ & $\begin{array}{l}\text { Mean U.S. establishment employment size in 3- } \\
\text { digit SIC industry, } 1995^{\mathrm{b}}\end{array}$ & 16.810 & 19.670 \\
\hline $\begin{array}{l}\text { Establishment size, } \\
\quad 1998\end{array}$ & $\begin{array}{l}\text { Mean U.S. establishment employment size in 3- } \\
\text { digit SIC industry, } 1998^{\mathrm{b}, \mathrm{e}}\end{array}$ & 16.160 & 18.290 \\
\hline Advertising intensity & $\begin{array}{l}\text { Advertising expenditures per dollar of industry } \\
\text { output, } 1997^{\mathrm{d}}\end{array}$ & 0.019 & 0.016 \\
\hline $\begin{array}{l}\text { Location quotient, } \\
\quad 1995\end{array}$ & $\begin{array}{l}\text { Percentage of state's establishments in 3-digit } \\
\text { SIC category divided by percentage of U.S. } \\
\text { establishments in the same category, } 1995^{\text {b }}\end{array}$ & 1.238 & 1.009 \\
\hline $\begin{array}{l}\text { Location quotient, } \\
\quad 1998\end{array}$ & $\begin{array}{l}\text { Percentage of state's establishments in 3-digit } \\
\text { SIC category divided by percentage of U.S. } \\
\text { establishments in the same category, } 1998 \text { be }\end{array}$ & 1.192 & 0.864 \\
\hline \multicolumn{4}{|c|}{$\begin{array}{l}\text { a Computed using Covered Employment and Wages data (ES-202). } \\
\text { b } \\
\text { b Computed using County Business Patterns data (U.S. Bureau of the Census). } \\
\text { c Investment data from } 1992 \text { benchmark input-output accounts, U.S. Bureau of Economic Analysis. Number } \\
\text { of industry establishments from County Business Patterns. } \\
{ }^{\mathrm{d}} \text { Computed using information from the U.S. input-output (IMPLAN) model. } \\
\text { e Variable constructed by combining employment data from multiple NAICS industrial categories. We used } \\
\text { a bridge provided by the U.S. Census Bureau to match the post-1997 industry employment data, based on } \\
\text { the NAICS system, to the 3-digit SIC category corresponding to the dependent (entry) variable. }\end{array}$} \\
\hline
\end{tabular}


where, $\sigma_{k}^{2}$ is the variance of aggregate industry employment in Maine calculated for the $k$-month intervals between January of 1994 and December of 1998, $\sigma_{i}^{2}$ is the variance of the first differences in monthly employment calculated over the entire period, and $k$ is the length of interval (Fawson, Thilmany, and Keith 1998). The 3-month and 6-month persistence variables measure short-term fluctuations in regional industry economic conditions, while the 12-month persistence variable measures longer-term fluctuations in employment.

A high variation in month-to-month employment change relative to the variation in $x$ month (e.g., 3-month, 6-month, and 12-month) employment levels, which results in a low value of the persistence measure, suggests that month-to-month employment gains or losses are dissipated over the $x$-month interval as employment fluctuates up and down (or down and up). On the other hand, a low variation in month-to-month employment change relative to the variation in $x$-month employment levels, which results in a high value of the persistence measure, means that employment gains or losses are maintained through the $x$-month cycle. Thus, high values of the persistence measure imply that industry employment is stable as employment shocks are maintained throughout the interval, while low values are a sign of instability.

The fluctuations in regional industry employment, captured in the persistence variables, reflect the expansions and contractions of existing businesses as well as business openings and closures (Davis, Haltiwanger, and Schuh 1996). The 6,886 entrants that began operations between 1996 and 1999 accounted for an average of 7.76 percent and 12.08 percent of industry employment in Maine during the first quarters of 1997 and 1998, respectively. Overall industry growth or decline occurring between January of 1994 and December of 1998, however, "will have little bias on the persistence measures" because they are standardized by the first-differences in monthly employment (Fawson, Thilmany, and Keith 1998).

Along with the employment persistence measures, the regression models control for the growth rate of U.S. industry employment (between 1994 and 1997) and U.S. industry employment size in 1995. Variables used in the analysis to represent barriers to entry include the dollar amount of investment per U.S. industry establishment, the average size of U.S. industry establishments, and advertising expenditures per dollar of U.S. industry output. The regression models also include location quotients to control for the industry's agglomeration in Maine.

\section{EMPIRICAL RESULTS}

The number of businesses that began operations per industry is estimated using a Poisson regression model in which the likelihood of observing $n_{j}$ new entrants is:

$$
f\left(n_{j}\right)=\left(e^{-\lambda j} \lambda_{j}^{n j}\right) / n_{j} ! \text { and } \ln \lambda_{j}=\beta^{\prime} X_{j},
$$


where $X_{j}$ is a vector of factors that influence entry and $\beta$ is a vector of estimated coefficients (Coughlin and Segev 2000; Greene 2000). A Poisson estimator is appropriate for the analysis of industry entry and, in other applications, business location given the count nature of the dependent variable (Chappell, Kimenyi, and Mayer 1990; Guimaraes, Figueiredo, and Woodward 2003).

Table 2 reports Poisson regression results on the determinants of industry entry in Maine. The employment persistence measures have a positive effect on the number of establishments that begin operations per industry, which suggests that entrants are attracted to sectors with high regional employment stability. Using the results from the regression analyses, we estimate that a 10 percent increase in the 3-month persistence of industry employment in Maine, with other variables held at their initial values, is associated with an average of 0.29 percent additional entrants per industry. Similar increases in the 6-month and 12-month persistence of industry employment in Maine are associated with an average of 0.26 percent and 0.30 percent additional entrants per sector.

TABLE 2

Poisson Regression Results on the Determinants of Industry Entry in Maine, 1996 to 1999

\begin{tabular}{|c|c|c|c|}
\hline Variable & \multicolumn{3}{|c|}{ Estimated Coefficients ${ }^{a}$} \\
\hline Constant & $\begin{array}{r}4.090^{*} \\
(115.100)\end{array}$ & $\begin{array}{r}4.095^{*} \\
(114.900)\end{array}$ & $\begin{array}{r}4.087^{*} \\
(115.200)\end{array}$ \\
\hline 3-month employment persistence & $\begin{array}{r}6.67 \mathrm{E}-03^{*} \\
(4.921)\end{array}$ & NA & NA \\
\hline 6-month employment persistence & NA & $\begin{array}{r}0.012^{*} \\
(4.246)\end{array}$ & NA \\
\hline $\begin{array}{l}\text { 12-month employment } \\
\text { persistence }\end{array}$ & NA & NA & $\begin{array}{c}0.028^{*} \\
(5.220)\end{array}$ \\
\hline Industry growth, 1994 to 1997 & $\begin{array}{c}0.751^{*} \\
(7.960)\end{array}$ & $\begin{array}{c}0.771^{*} \\
(8.170)\end{array}$ & $\begin{array}{r}0.751^{*} \\
(7.990)\end{array}$ \\
\hline Industry size, 1995 & $\begin{array}{l}4.35 \mathrm{E}-07^{*} \\
(73.860)\end{array}$ & $\begin{array}{l}4.34 \mathrm{E}-07^{*} \\
(73.830)\end{array}$ & $\begin{array}{l}\text { 4.37E- } 07^{*} \\
(73.810)\end{array}$ \\
\hline Investment & $\begin{array}{l}-3.81 \mathrm{E}-07^{*} \\
(-6.921)\end{array}$ & $\begin{array}{l}-3.81 \mathrm{E}-07^{*} \\
(-6.910)\end{array}$ & $\begin{array}{l}-3.74 \mathrm{E}-07^{*} \\
(-6.798)\end{array}$ \\
\hline Establishment size, 1995 & $\begin{array}{r}-0.021^{*} \\
(-19.250)\end{array}$ & $\begin{array}{r}-0.021^{*} \\
(-19.280)\end{array}$ & $\begin{array}{r}-0.022^{*} \\
(-19.340)\end{array}$ \\
\hline Advertising intensity & $\begin{array}{l}-15.780^{*} \\
(-17.270)\end{array}$ & $\begin{array}{l}-15.890^{*} \\
(-17.400)\end{array}$ & $\begin{array}{l}-15.750^{*} \\
(-17.250)\end{array}$ \\
\hline Location quotient, 1995 & $\begin{array}{r}0.097^{*} \\
(7.824)\end{array}$ & $\begin{array}{r}0.096^{*} \\
(7.745)\end{array}$ & $\begin{array}{r}0.098^{*} \\
(7.910)\end{array}$ \\
\hline Chi-squared significance level & $\begin{array}{r}3,923.700 \\
.000\end{array}$ & $\begin{array}{r}3,917.900 \\
.000\end{array}$ & $\begin{array}{c}3,926.5000 \\
.000\end{array}$ \\
\hline Number of observations & 123 & 123 & 123 \\
\hline
\end{tabular}


The traditional entry variables included in the regression models have a significant effect on the entry decisions of Maine businesses. For these variables, there are no qualitative differences among the results from the three models presented in Table 2. The estimates discussed below are from the analysis presented in the left-hand column of results. Empirical results suggest that the growth and size of the industry nationally have a positive effect on the number of entrants in Maine. A 10 percent increase in the U.S. industry growth rate leads to an average of 1.04 percent additional entrants per industry, while a similar increase in industry size is associated with, on average, a 2.40 percent increase in entry.

Capital requirements, economies of scale, and advertising intensity are found to be barriers to entry. Other things being equal, a 10 percent increase in the value of structures and investment per establishment is associated with, on average, a 0.57 percent decrease in entry. A 10 percent increase in mean industry establishment size nationally leads to, on average, a 3.46 percent decrease in entry. A similar increase in the advertising-output ratio results in an average of 2.99 percent fewer entrants per industry in Maine. Finally, the regression results suggest that industry agglomeration has a positive effect on entry. A 10 percent increase in the location quotient is associated with an average increase in entry of 1.21 percent.

\section{EFFECTS OF INDUSTRY INSTABILITY ON ENTRY BETWEEN 1999 AND 2000}

As indicated above, entry is measured over a three-year period from 1996 to 1999, and the stability variables are calculated using monthly employment data from January of 1994 to December of 1998. Although the new entrants made up a small percentage of the total industry employment figures used to compute the stability measures, it is possible that entry occurring between 1996 and 1999 may influence the employment persistence variables. In related studies, Caves and Porter (1978) and Meisel (1981) found that the entry of new competitors increases business-level market share instability. To minimize any potential problems related to endogeneity between industry entry and stability, we examine the effects of instability, measured between January of 1994 and December of 1998 , on the entry decisions of 1,765 establishments that began operations in Maine between the first quarters of 1999 and 2000.

The dependent variable is a count of the number of Maine businesses that began operations per sector between the first quarters of 1999 and 2000. As before, the choice set consists of the 123 three-digit SIC industries that had ten or more entrants in Maine between 1996 and 1999. The regression models also control for the traditional entry determinants included in the previous analysis. The industry growth, employment size, and average establishment size variables, constructed using U.S. industry employment data from after 1997, are based on slightly different industries than those represented in the dependent variable because of changes in the industrial classification system from SIC to NAICS. We used a bridge provided by the U.S. Census Bureau to match the post- 
1997 U.S. industry employment data, based on the NAICS system, to the proper SIC category corresponding to the dependent variable.

Table 3 shows empirical results on the determinants of industry entry in Maine between 1999 and 2000. Similar to what we found in the previous analysis, the persistence of industry employment in Maine, measured between January of 1994 and December of 1998, has a positive effect on the number of establishments that begin operations per industry between 1999 and 2000. A 10 percent increase in the 3-month persistence of industry employment in Maine, with other variables held at their initial values, is associated with an average of 0.78 percent additional entrants per industry. Similar increases in the 6-month and 12-month persistence of industry employment in Maine are associated with an average of 0.81 percent and 0.76 percent additional entrants per industry, respectively.

\section{TABLE 3}

Poisson Regression Results on the Determinants of Industry Entry in Maine, 1999 to 2000

\begin{tabular}{|c|c|c|c|}
\hline \multirow{2}{*}{$\frac{\text { Variable }}{\text { Constant }}$} & \multicolumn{3}{|c|}{ Estimated Coefficients $^{\text {a }}$} \\
\hline & $\begin{array}{c}2.623^{*} \\
(34.640)\end{array}$ & $\begin{array}{c}2.623^{*} \\
(34.650)\end{array}$ & $\begin{array}{c}2.617^{*} \\
(34.510)\end{array}$ \\
\hline 3-month employment persistence & $\begin{array}{c}0.018^{*} \\
(7.265)\end{array}$ & NA & NA \\
\hline 6-month employment persistence & NA & $\begin{array}{l}0.036^{*} \\
(7.237)\end{array}$ & NA \\
\hline $\begin{array}{l}\text { 12-month employment } \\
\text { persistence }\end{array}$ & NA & NA & $\begin{array}{l}0.0720^{*} \\
(7.283)\end{array}$ \\
\hline Industry growth, 1998 to 2000 & $\begin{array}{l}-0.052 \\
(-0.139)\end{array}$ & $\begin{array}{l}-0.038 \\
(-0.101)\end{array}$ & $\begin{array}{l}8.47 \mathrm{E}-03 \\
(0.023)\end{array}$ \\
\hline Industry size, 1998 & $\begin{array}{l}\text { 4.47E-07* } \\
(42.410)\end{array}$ & $\begin{array}{l}4.45 \mathrm{E}-07^{*} \\
(42.270)\end{array}$ & $\begin{array}{l}4.502 \mathrm{E}-07^{*} \\
(42.540)\end{array}$ \\
\hline Investment & $\begin{array}{l}-3.66 \mathrm{E}-07^{*} \\
(-3.555)\end{array}$ & $\begin{array}{l}-3.63 \mathrm{E}-07^{*} \\
(-3.526)\end{array}$ & $\begin{array}{l}-3.55 \mathrm{E}-07^{*} \\
(-3.447)\end{array}$ \\
\hline Establishment size, 1998 & $\begin{array}{l}-0.023^{*} \\
(-9.426)\end{array}$ & $\begin{array}{l}-0.023^{*} \\
(-9.417)\end{array}$ & $\begin{array}{l}-0.023^{*} \\
(-9.523)\end{array}$ \\
\hline Advertising intensity & $\begin{array}{l}-17.530^{*} \\
(-9.217)\end{array}$ & $\begin{array}{l}-17.600^{*} \\
(-9.263)\end{array}$ & $\begin{array}{l}-17.510^{*} \\
(-9.214)\end{array}$ \\
\hline Location quotient, 1998 & $\begin{array}{c}0.123^{*} \\
(5.250)\end{array}$ & $\begin{array}{c}0.122 * \\
(5.200)\end{array}$ & $\begin{array}{c}0.125^{*} \\
(5.324)\end{array}$ \\
\hline Chi-squared significance level & $\begin{array}{r}1,308.600 \\
.000\end{array}$ & $\begin{array}{r}1,308.200 \\
.000\end{array}$ & $\begin{array}{r}1,309.100 \\
.000\end{array}$ \\
\hline Number of observations & 123 & 123 & 123 \\
\hline
\end{tabular}


As before, the estimates discussed below are from the analysis presented in the lefthand column of results. Empirical results suggest that the size of the industry nationally in 1998 has a positive effect on the number of entrants between 1999 and 2000. On the other hand, contrary to what we found in the previous analysis, U.S. industry employment growth between 1998 and 2000 does not have a significant effect on the entry decisions of Maine establishments. Once again, capital requirements, economies of scale and advertising intensity are found to be barriers to entry. Finally, the regression results suggest that industry agglomeration in Maine has a positive effect on entry between 1999 and 2000 .

\section{ENTRY BETWEEN 1996 AND 1999 ACROSS A LARGER CHOICE SET OF INDUSTRIES}

The entry analysis presented above uses a choice set of sectors that had ten or more establishments begin operations in Maine between 1996 and 1999. Although these industries cover about 70 percent of total state employment in 1996, they account for only 37.5 percent (123 of 328) of the three-digit SIC sectors (not including the major industrial category of agricultural services, forestry, and fishing) that employed workers in Maine between 1996 and 1999. Thus, the results presented in Tables 2 and 3 pertain to sectors that are responsible for the bulk of the economic activity in Maine, but they may not apply to a larger group of industries.

In this section, we expand the choice set from the original 123 sectors to 328 threedigit sectors (not including the major industrial category of agricultural services, forestry, and fishing) that employed workers in Maine between 1996 and 1999. These sectors had an average of 22.4 entrants over the three-year period. We are unable to expand the choice set to include sectors that had zero employment because the persistence measures are undefined in cases where employment levels do not change (e.g., equal zero) over the entire period of analysis. These 328 sectors accounted for 93.2 percent $(6,385,340$ out of $6,738,541)$ of all U.S. establishments and 94.8 percent $(95,277,668$ out of $102,198,864)$ of total U.S. employment in 1996.

A comparison of the descriptive statistics computed from the original sample of 123 sectors (in Table 1) and the larger group of 328 industries provides some insights into the factors that affect entry. The average 3-month (3.182), 6-month (1.662), and 12-month (0.806) persistence measures are all lower in the group of 328 industries than in the smaller sample of high-entry sectors. This suggests that employment stability is higher in the sectors with ten or more entrants than in industries that experienced less entry. The sample of industries with ten or more entrants has a higher average 1994 to 1997 U.S. employment growth rate (10.4 percent compared to 7.0 percent) and a larger average 1995 U.S. employment size (530,586 workers compared to 289,791 workers) than the larger group of 328 industries.

Barriers to entry also appear to be lower in the sample of sectors with ten or more entrants than in the larger group of industries. For example, the average size of U.S. 
industry establishments in the sample of high-entry sectors is 16.81 workers, compared to 46.44 workers in the larger group of industries. Likewise, the dollar amount of new structures and investment per U.S. industry establishment averaged $\$ 151,840$ in the sectors with ten or more entrants, compared to $\$ 372,370$ in the larger sample.

Table 4 shows results on the determinants of entry between 1996 and 1999 across the larger group of 328 three-digit SIC sectors. The industry employment persistence measures have a positive effect on the number of entrants per sector. This suggests that as in the previous analysis, establishments are attracted to sectors with stable employment over time. Ten percent increases in the 3-month, 6-month, and 12-month persistence measures are associated with 0.69 percent, 0.68 percent, and 0.69 percent increases in the number of entrants, respectively. These elasticity estimates are slightly more than twice as large as those reported in the earlier analysis that examined 1996 to 1999 entry across the smaller sample of industries.

TABLE 4

Poisson Regression Results on Entry Across 328 Three-Digit SIC Sectors, 1996 to 1999

\begin{tabular}{lccc}
\hline Variable & \multicolumn{3}{c}{ Estimated Coefficients ${ }^{\mathrm{a}}$} \\
\hline Constant & $3.521^{*}$ & $3.531^{*}$ & $3.527^{*}$ \\
& $(119.600)$ & $(119.900)$ & $(120.100)$ \\
3-month employment persistence & $0.022^{*}$ & $\mathrm{NA}$ & $\mathrm{NA}$ \\
& $(16.670)$ & & \\
6-month employment persistence & $\mathrm{NA}$ & $0.041^{*}$ & $\mathrm{NA}$ \\
& & $(15.420)$ & \\
12-month employment persistence & $\mathrm{NA}$ & $\mathrm{NA}$ & $0.085^{*}$ \\
& & & $(16.320)$ \\
Industry growth, 1994 to 1997 & $0.566^{*}$ & $0.582^{*}$ & $0.560^{*}$ \\
& $(9.356)$ & $(9.617)$ & $(9.234)$ \\
Industry size, 1995 & $5.39 \mathrm{E}-07^{*}$ & $5.35 \mathrm{E}-07^{*}$ & $5.42 \mathrm{E}-07^{*}$ \\
& $(100.500)$ & $(100.100)$ & $(100.800)$ \\
Investment & $-7.42 \mathrm{E}-07^{*}$ & $-7.51 \mathrm{E}-07^{*}$ & $-7.48 \mathrm{E}-07^{*}$ \\
& $(-13.900)$ & $(-14.040)$ & $(-13.990)$ \\
Establishment size, 1995 & $-0.028^{*}$ & $-0.028^{*}$ & $-0.028^{*}$ \\
& $(-32.600)$ & $(-32.580)$ & $(-32.760)$ \\
Advertising intensity & $-15.160^{*}$ & $-15.400^{*}$ & $-15.240^{*}$ \\
& $(-17.440)$ & $(-17.730)$ & $(-17.550)$ \\
Location quotient, 1995 & $0.156^{*}$ & $0.154^{*}$ & $0.158^{*}$ \\
& $(16.340)$ & $(16.140)$ & $(16.510)$ \\
Chi-squared significance level & $10,044.500$ & $10,012.600$ & $10,036.200$ \\
& .000 & .000 & .000 \\
Number of observations & 328 & 328 & 328 \\
\hline a Figures in parentheses are t-statistics. & \multicolumn{3}{c}{} \\
* indicates significance at 1 percent level. & & & \\
\hline
\end{tabular}


As in the analysis that focused on high-entry industries, our results on entry across the larger group of sectors suggest that the growth and size of the U.S. industry, as well as the level of industry agglomeration in Maine, have a positive effect on the number of entrants. Likewise, the traditional barriers to entry - captured in our proxy variables that represent capital requirements, economies of scale, and advertising intensity - have a negative effect on the number of businesses that began operations per industry.

\section{SUMMARY AND CONCLUSIONS}

To put our findings into perspective, Tables 5 and 6 present empirical results on entry in high- and low-stability industries in Maine. Table 5 shows information on the 20 highentry sectors with the highest levels of 6-month employment persistence in Maine, listed in order from highest to lowest stability. Eleven of the high-stability sectors are subsectors of the services major industrial category. These include several health care sectors, residential care, computer and data processing services, individual and family services, and job training services. Other high stability sectors include personal credit institutions, retail bakeries, drug stores, and paper product wholesalers.

Table 5 shows the actual numbers of entrants per sector between 1996 and 1999, as well as the effects of a decrease in industry employment persistence on estimated entry levels. These effects are calculated as the percentage difference between the estimated number of industry entrants given a decrease in 6-month employment persistence to the sample mean, and the estimated number of entrants with all explanatory variables held at initial values. The results suggest that a decrease in stability from current levels to the sample mean would lead to substantially fewer entrants in several of the very high stability sectors. On the other hand, such a reduction in stability would have only modest effects on entry in sectors that are outside the top 10 to 15 in terms of highest stability.

The 20 high-entry sectors with the lowest levels of 6-month employment persistence in Maine, listed in order from lowest to highest stability, are shown in Table 6. Whereas the five industries with the highest stability are all sub-sectors of the services industry, none of the five industries with the lowest stability are part of the services sector. However, 11 of the low-stability sectors are part of the retail trade (six sectors) and services (five sectors) industries. The manufacturing sector also includes four of the three-digit SIC industries with the lowest 6-month employment persistence in Maine. Some of the sectors with the lowest levels of employment stability include logging, department stores, miscellaneous wood products, family clothing stores, and child day care services.

Table 6 shows actual levels of entry in the low stability industries as well as the effects of an increase in employment persistence on the estimated number of entrants. These effects are calculated as the percentage difference between the estimated number of entrants given an increase in 6-month employment persistence to the sample mean, and the estimated number of entrants with all explanatory variables held at initial values. The results, estimated using coefficients from the analysis of entry in the 328 three-digit SIC 
TABLE 5

Entry in Selected High-Stability Industries

\begin{tabular}{|c|c|c|c|}
\hline Industry Title and SIC Code ${ }^{a}$ & $\begin{array}{l}\text { Entry, } \\
96 \text { to } 99\end{array}$ & $\begin{array}{l}\text { Estimated effect of } \\
\text { decrease in stability }\end{array}$ & $\begin{array}{l}\text { Estimated effect of } \\
\text { decrease in stability }\end{array}$ \\
\hline Residential care $(8360)$ & 73 & $-19.6 \%$ & $-54.2 \%$ \\
\hline $\begin{array}{l}\text { Computer and data processing } \\
\text { services } 7370 \text { ) }\end{array}$ & 189 & $-19.1 \%$ & $-53.2 \%$ \\
\hline $\begin{array}{l}\text { Offices and clinics of medical } \\
\text { doctors }(8010)\end{array}$ & 137 & $-18.9 \%$ & $-52.8 \%$ \\
\hline $\begin{array}{l}\text { Health and allied services, n.e.c. } \\
\quad(8090)\end{array}$ & 25 & $-17.3 \%$ & $-49.4 \%$ \\
\hline $\begin{array}{l}\text { Individual and family services } \\
\quad(8320)\end{array}$ & 100 & $-9.3 \%$ & $-30.3 \%$ \\
\hline Holding offices (6710) & 12 & $-8.6 \%$ & $-28.4 \%$ \\
\hline $\begin{array}{l}\text { Job training and related services } \\
(8330)\end{array}$ & 12 & $-5.8 \%$ & $-20.5 \%$ \\
\hline $\begin{array}{l}\text { Personal credit institutions } \\
\quad(6140)\end{array}$ & 12 & $-5.7 \%$ & $-20.2 \%$ \\
\hline $\begin{array}{l}\text { Offices of other health } \\
\text { practitioners }(8040)\end{array}$ & 90 & $-5.6 \%$ & $-20.1 \%$ \\
\hline $\begin{array}{l}\text { Security and commodity services } \\
(6280)\end{array}$ & 33 & $-4.9 \%$ & $-17.8 \%$ \\
\hline $\begin{array}{l}\text { Miscellaneous non-durable } \\
\text { goods (5190) }\end{array}$ & 35 & $-4.6 \%$ & $-16.9 \%$ \\
\hline Retail bakeries $(5460)$ & 42 & $-3.6 \%$ & $-14.1 \%$ \\
\hline $\begin{array}{l}\text { Miscellaneous business services } \\
\quad \text { (7380) }\end{array}$ & 158 & $-2.7 \%$ & $-11.0 \%$ \\
\hline $\begin{array}{l}\text { Miscellaneous equipment rental } \\
\text { and leasing (7350) }\end{array}$ & 37 & $-1.9 \%$ & $-8.7 \%$ \\
\hline $\begin{array}{l}\text { Drug stores and proprietary } \\
\text { stores }(5910)\end{array}$ & 34 & $-1.2 \%$ & $-6.3 \%$ \\
\hline $\begin{array}{l}\text { Motor vehicles, parts, and } \\
\text { supplies (5010) }\end{array}$ & 36 & $-1.2 \%$ & $-6.3 \%$ \\
\hline Paper and paper products (5110) & 16 & $-1.1 \%$ & $-5.8 \%$ \\
\hline $\begin{array}{l}\text { Mailing, reproduction, } \\
\text { stenographic }(7330)\end{array}$ & 28 & $-0.5 \%$ & $-4.0 \%$ \\
\hline Local and suburban & & & \\
\hline $\begin{array}{c}\text { transportation }(4110) \\
\text { Electrical repair shops }(7620)\end{array}$ & $\begin{array}{l}11 \\
11\end{array}$ & $\begin{array}{l}-0.4 \% \\
-0.3 \%\end{array}$ & $\begin{array}{l}-3.6 \% \\
-3.1 \%\end{array}$ \\
\hline
\end{tabular}

${ }^{a}$ Table includes the 20 high-entry 3-digit SIC categories with the highest 6-month employment persistence, shown in order from highest to lowest stability.

${ }^{b}$ This effect is calculated as the percentage difference between the estimated number of entrants given a decrease in 6-month employment persistence to the sample mean, and the estimated number of entrants with all explanatory variables held at initial values. Coefficient estimates are from the analysis of entry in the 123 3-digit SIC sectors with ten or more new businesses in Maine between 1996 and 1999.

${ }^{\mathrm{c}}$ This effect is calculated as the percentage difference between the estimated number of entrants given a decrease in 6-month employment persistence to the sample mean, and the estimated number of entrants with all explanatory variables held at initial values. Coefficient estimates are from the analysis of entry in the 328 3-digit SIC sectors that employed workers in Maine between 1996 and 1999. 
TABLE 6

Entry in Selected Low Stability Industries

\begin{tabular}{|c|c|c|c|}
\hline Industry Title and SIC Code ${ }^{a}$ & $\begin{array}{l}\text { Entry, } \\
96 \text { to } 99\end{array}$ & $\begin{array}{l}\text { Estimated effect of } \\
\text { increase in stability }\end{array}$ & $\begin{array}{l}\text { Estimated effect of } \\
\text { increase in stability }{ }^{c}\end{array}$ \\
\hline \multicolumn{4}{|l|}{ Miscellaneous manufactures } \\
\hline (3990) & 19 & $2.6 \%$ & $6.9 \%$ \\
\hline Logging (2410) & 117 & $2.6 \%$ & $6.9 \%$ \\
\hline Non-store retailers (5960) & 19 & $2.5 \%$ & $6.4 \%$ \\
\hline \multicolumn{4}{|l|}{ Real estate operators and lessors } \\
\hline$(6510)$ & 62 & $2.5 \%$ & $6.3 \%$ \\
\hline Department stores (5310) & 21 & $2.4 \%$ & $6.2 \%$ \\
\hline \multicolumn{4}{|l|}{ Miscellaneous general } \\
\hline $\begin{array}{c}\text { merchandise stores (5390) } \\
\text { Miscellaneous shonning goods }\end{array}$ & 24 & $2.4 \%$ & $6.2 \%$ \\
\hline stores (5940) & 147 & $2.3 \%$ & $5.8 \%$ \\
\hline \multicolumn{4}{|l|}{ Miscellaneous wood products } \\
\hline Family clothing stores (5650) & 13 & $2.3 \%$ & $5.7 \%$ \\
\hline \multicolumn{4}{|l|}{ Miscellaneous plastics products, } \\
\hline \multicolumn{3}{|l|}{ Automotive services, except } & $5.7 \%$ \\
\hline \multicolumn{4}{|l|}{ Photographic studios, portrait } \\
\hline \multicolumn{4}{|l|}{ Miscellaneous personal services } \\
\hline \multicolumn{3}{|l|}{ Passenger transportation } & $5.5 \%$ \\
\hline \multicolumn{4}{|l|}{ Mortgage bankers and brokers } \\
\hline Child day care services (8350) & 121 & $2.2 \%$ & $5.5 \%$ \\
\hline Commercial banks (6020) & 82 & $2.2 \%$ & $5.3 \%$ \\
\hline \multicolumn{4}{|l|}{ Plumbing, heating, air- } \\
\hline $\begin{array}{l}\text { Miscellaneous amusement, } \\
\text { recreation services (7990) }\end{array}$ & 80 & $2.1 \%$ & $5.3 \%$ \\
\hline Women's clothing stores (5620) & 24 & $2.1 \%$ & $5.2 \%$ \\
\hline \multicolumn{4}{|c|}{$\begin{array}{l}\text { a Table includes the } 20 \text { high-entry 3-digit SIC categories with the lowest 6-month employment persis- } \\
\text { tence, shown in order from lowest to highest stability. } \\
\text { b This effect is calculated as the percentage difference between the estimated number of entrants given } \\
\text { an increase in 6-month employment persistence to the sample mean, and the estimated number of } \\
\text { entrants with all explanatory variables held at initial values. Coefficient estimates are from the analy- } \\
\text { sis of entry in the } 123 \text { 3-digit SIC sectors with ten or more new businesses in Maine between } 1996 \text { and } \\
1999 \text {. }\end{array}$} \\
\hline
\end{tabular}


sectors that employed workers in Maine between 1996 and 1999, suggest that an increase in persistence from current levels to the sample mean would lead to a 5 to 7 percent increase in entry. The results, estimated using coefficients from the analysis of highentry sectors, suggest that an increase in persistence from current levels to the sample mean would lead to a 2 to 3 percent increase in entry.

In conclusion, our empirical findings imply that the persistence of industry employment in Maine has a positive effect on entry. These results, which suggest that establishments are attracted to sectors with high employment stability, are robust to the time period over which entry is measured and the size of the industry choice set. Explanations consistent with these results are that instability discourages entry either by increasing the cost of adjusting an establishment's workforce over time or by increasing the opportunity cost of investment.

An interesting extension to this research would be to examine the link between industry instability and entry using data from other states. It is possible that industries with stable employment in Maine may experience high fluctuations elsewhere and vice versa. Given the results reported in this paper, we would expect to find a positive relationship between industry employment persistence and entry in other states as well. A possible limitation to conducting this analysis at a national scale is that persistence measures based on aggregate U.S. industry employment figures may not accurately capture employment fluctuations at the regional level, which is where entry decisions are often made.

\section{REFERENCES}

Audretsch, D., 1995. Innovation and Industry Evolution. MIT Press: Cambridge, MA.

Brewer, H., 1985. "Measures of Diversification: Predictors of Regional Economic Instability," Journal of Regional Science 25, 463-470.

Brown, D. and J. Pheasant, 1985. "A Sharpe Portfolio Approach to Regional Economic Instability," Journal of Regional Science 25, 51-63. , 1987. "Sources of Cyclical Employment Instability in Rural Counties," American Journal of Agricultural Economics 69, 819-827.

Caves, R. and M. Porter, 1978. "Market Structure, Oligopoly, and Stability of Market Shares," Journal of Industrial Economics 26, 289-313.

Chappell, W., M. Kimenyi, and W. Mayer, 1990. "A Poisson Probability Model of Entry and Market Structure with an Application to U.S. Industries during 1972-77," Southern Economic Journal 56, 918-927.

Cochrane, J., 1988. "How Big is the Random Walk in GNP?" Journal of Political Economy 96, 893-920.

Conroy, M., 1975. "The Concept and Measurement of Regional Industrial Diversification," Southern Economic Journal 41, 492-505.

Coughlin, C. and E. Segev, 2000. "Location Determinants of New Foreign-Owned Manufacturing Plants," Journal of Regional Science 40, 323-351. 
Davis, S., J. Haltiwanger, and S. Schuh, 1996. Job Creation and Destruction. MIT Press: Cambridge, MA.

Deutsch, L., 1984. "Entry and the Extent of Multiplant Operations," Journal of Industrial Economics 32, 477-487.

Dixit, A., 1997. "Investment and Employment Dynamics in the Short Run and the Long Run," Oxford Economic Papers 49, 1-20.

Evans, L.B. and J. Siegfried, 1992. "Entry and Exit in United States Manufacturing Industries from 1977 to 1982," in D. Audretsch and J. Siegfried (eds.), Empirical Studies in Industrial Organization: Essays in Honor of Leonard W. Weiss. Kluwer Academic Publishers: Dordrecht, Netherlands.

Fawson, C., D. Thilmany, and J. Keith, 1998. "Employment Stability and the Role of Sectoral Dominance in Rural Economies," American Journal of Agricultural Economics 80, 521-533.

Geroski, P., 1995. "What do We Know about Entry?” International Journal of Industrial Organization 13, 421-440.

Greene, W., 2000. Econometric Analysis. Prentice Hall: Upper Saddle River, NJ.

Guimaraes, P., O. Figueiredo, and D. Woodward, 2003. "A Tractable Approach to the Firm Location Problem," Review of Economics and Statistics 85, 201-204.

Hause, J. and G. DuRietz, 1984. "Entry, Industry Growth, and the Microdynamics of Industry Supply," Journal of Political Economy 92, 733-757.

Kessides, I., 1986. "Advertising, Sunk Costs, and Barriers to Entry," Review of Economics and Statistics 68, 84-95.

Krugman, P., 1991. Geography and Trade. MIT Press: Cambridge, MA.

McGuckin, R., 1972. "Entry, Concentration Change, and Stability of Market Shares," Southern Economic Journal 38, 363-370.

Meisel, J., 1981. "Entry, Multiple-Brand Firms and Market Share Instability," Journal of Industrial Economics 29, 375-384.

Orr, D., 1974. "The Determinants of Entry: A Study of Canadian Manufacturing Industries," Review of Economics and Statistics 56, 58-66.

Pindyck, R., 1988. "Irreversible Investment, Capacity Choice, and the Value of the Firm," American Economic Review 78, 969-985.

Porter, M., 2000. "Location, Competition, and Economic Development: Local Clusters in a Global Economy," Economic Development Quarterly 14, 15-34.

Smith, E., 1990. "Economic Stability and Economic Growth in Rural Communities: Dimensions Relevant to Local Employment Creation Strategy," Growth and Change 21, 3-18.

Smith, S. and C. Gibson, 1988. "Industrial Diversification in Nonmetropolitan Counties and its Effects on Economic Stability," Western Journal of Agricultural Economics $13,193-201$. 